\title{
References:
}

1. Miłosz C., thum. Robert Haas, The New Yorker, May 20, 1996, 62 p.

2. Miłosz C., O! Edward Hopper (1882-1967), Pokój Hotelowy, Thyssen Collection, Lugano, Miłosz Czesław, To, Kraków 2001, 29-31 p.

3. Szymborska W., Kobiety Rubensa, Warszawa 1962, PIW, 58 p.

4. Grochowiak S., Ikar, Grochowiak Stanisław: Ikar. Zeszyty Naukowe. Wyższa Szkoła Pedagogiczna im. Powstańców Śląskich w Opolu. Filologia Polska 1993 z. 31 p.

5. Grochowiak S., Płonąca żyrafa, Wybór poezji, J. Łukasiewicz, Wrocław 2000, $36 \mathrm{p}$.

6. Barcelan E., Poezja jako semiotyka sztuki, w: G.Królikiewiecz (red.), Literatura a malarsto - malarstwo a literatura. Panorama myśli polskiej XX wieku, Wydawnictwo Uniwersytetu Jagiellońskiego, Kraków 2009. 191 p.

7. Dziadek A., Obrazy i wiersze, Wydawnictwo Uniwersytetu Śląskiego, Katowice 2004. 148 p.

8. Grodecka A., Wiersze o obrazach. Studium z dziejów ekfrazy, Wydawnictwo Naukowe Uniwersytetu im. Adama Mickiewicza, Poznań 2009. $200 \mathrm{p}$.

DOI https://doi.org/10.30525/978-9934-26-004-9-79

\section{ВИКОРИСТАННЯ АРТ-ТЕРАПЕВИЧНИХ МЕТОДІВ У ВИКЛАДАННІ МИСТЕЦТВА}

Білостоцька О. В.

кандидат педагогічних наук, доцент,

дочент кафедри музично-інструментальної підготовки вчителя Комунального закладу «Харківська гуманітарно-педагогічна академія» Харківської обласної ради м. Харків, Україна

У контексті арт-терапевтичного впливу широкого огляду набули питання застосування музики та звуків 3 метою оздоровлення та гармонізації психофізіологічного стану особистості (І. Волженцева, В. Драганчук, М. Кісєльова, О. Копитін, Д. Кемпбел, Г. Лозанов, В.Нікітін, В. Петрушин, Г. Побережна, С. Нечай, Н. Савельева-Кулик, М. Чепига та ін.) [1-3].

Арт-терапія - це вид психотерапії та психологічної корекції, заснований на мистецтві та творчості. Термін "арт-терапія" введений 
А. Хіллом, який наголошував на тому, що мистецтво може здійснювати позитивний вплив на психіку особи. Дослідник стверджував, що внутрішнє "Я" суб'єкта відображається у візуальних формах того часу, коли він (суб'єкт) спроможний виявити себе у творчості.

Креативна терапія. Арт-терапія, в основі якої лежать ідеї Фрейда та Юнга, - це не стільки лікування, скільки розвиток у людини властивої ій креативності, гармонізація та розвиток особистості, що допомагає при вирішенні проблем. Згідно 3 Фрейдом, внутрішнє «Я» людини виявляється у візуальній формі кожного разу, коли вона спонтанно щось малює чи ліпить, а образотворче мистецтво, маючи багато спільного 3 фантазіями та сновидіннями, виконує роль, що компенсує та знімає психічну напругу. Юнг наголошував на важливості використання персональних та універсальних символів. Центральною фігурою в арттерапевтичному процесі $є$ не пацієнт як хвора людина, а особистість, яка прагне до саморозвитку й розширення діапазону своїх можливостей. Він уважав, що пацієнт, спираючись на «трансцендентні» властивості символів і власний творчий потенціал, здатен досягти самозцілення, і що символічні образи несуть у собі способи вирішення внутрішньопсихічних конфліктів. Поступово, протягом XX століття, арт-терапія стає невід'ємною частиною соціальних заходів профілактичного й реабілітаційного характеру, медичної, психотерапевтичної та педагогічної практики.

Арт-терапія для дітей - це унікальний спосіб психологічної корекції, що допомагає дитині побачити світ гостинним і прекрасним. У вузькому сенсі слова під арт-терапією зазвичай мається на увазі терапія образотворчим мистецтвом 3 метою впливу на психоемоційний стан дитини.

Арт-терапія має очевидні переваги перед іншими, заснованими винятково на вербальній комунікації, формами психотерапевтичної роботи, а саме:

- практично кожна людина (незалежно від свого віку, культурного досвіду і соціального стану) може брати участь в арт-терапевтичній роботі, яка не вимагає від неї яких-небудь здібностей до образотворчої діяльності чи художніх навичок. Тому арт-терапія не має обмежень у використанні. Немає підстав говорити i про наявність яких-небудь протипоказань до участі тих чи інших людей в арт-терапевтичному процесі;

- арт-терапія є засобом переважно невербального спілкування. Це робить їі особливо цінною для тих, хто недостатньо добре володіє мовою, має труднощі в словесному описі своїх переживань. Символічна мова $\epsilon$ однією 3 основ образотворчого мистецтва, дозволяє людині найчастіше більш точно виразити свої переживання, по-новому глянути 46 
на ситуацію і життєві проблеми i знайти завдяки цьому шлях до їх вирішення;

- образотворча діяльність є могутнім засобом зближення людей, своєрідним «мостом» між фахівцем і дитиною. Це особливо цінно в ситуаціях взаємного відчуження, при ускладненні в налагодженні контактів, у спілкуванні 3 приводу занадто складного і делікатного предмета;

- арт-терапія є засобом вільного самовираження і самопізнання, припускає атмосферу довіри, терпимості й уваги до внутрішнього світу людини;

- продукти образотворчої діяльності є об’єктивним свідченням настроїв i думок людини, що дозволяє використовувати їх для динамічної оцінки стану, проведення відповідних досліджень;

- арт-терапевтична робота в більшості випадків викликає в людей позитивні емоції, допомагає перебороти апатію і безініціативність, сформувати більш активну життєву позицію;

- арт-терапія заснована на мобілізації творчого потенціалу людини, внутрішніх механізмів саморегуляції і зцілення. Вона відповідає фундаментальній потребі в самоактуалізації - розкритті широкого спектра можливостей людини й утвердження нею свого індивідуальнонеповторного способу буття у світі.

- арт-терапія - творчий пошук. Переживання моменту творіння дає сили для подолання перешкод i вирішення внутрішніх i зовнішніх конфліктів.

Розглянутий метод психологічної допомоги вельми корисний дітям 3 різними психологічними захворюваннями, такими як: порушення мови або затримка розумового розвитку. Вправи арт-терапії допомагають дітям побороти агресію і негатив, навчитися виражати свої погляди i почуття, підняти самооцінку, вирішити наявні конфлікти і проблеми, а також привести свої думки і почуття до гармонії.

У загальному значенні метою арт-терапії є «перемикання» активності півкуль мозку. Як відомо, ліва півкуля відповідає за розум і свідомість. Вона $є$ цензором, який не дозволяє виходити назовні емоціям і почуттям. Даний метод психологічної допомоги, за допомогою творчої діяльності, допомагає активізувати роботу лівої півкулі, запускаючи тим самим несвідомі процеси, які і випускають назовні справжні переживання. Така робота призводить до усвідомлення і виправлення внутрішніх страхів, комплексів і «затискачів».

На сьогоднішній день існує безліч методів арт-терапії, а все тому, що цей спосіб психологічної допомоги охоплює всі сфери мистецтва та творчості. 
1. Ізотерапія (робота, пов'язана 3 образотворчим мистецтвом, ліпленням і малюванням дозволяє розкрити свій творчий потенціал, позбутися комплексів, знайшовши впевненість у собі).

Малювання - одна 3 основних технік арт-терапії. Малювати можна чим завгодно, але слід пам'ятати, що нервовій людині краще використовувати крейду, тому що акварель, яка розтікається, може спровокувати тривогу. Крейду легше контролювати, i людина переносить це відчуття на життя. А якщо людина закомплексована, то краще малювати аквареллю - це допоможе їй відчути себе розкутою. Для ліплення використовуються пластилін, глина, тісто. Учасники групи можуть виліпити свій страх, подивитись і поламати, а потім створити протилежний стан - радості, щастя.

2. Казкотерапія (знайомство 3 казками, які допомагають дітям позбутися комплексів, знайти вихід зі скрутного становища, не втрачати сили і віру).

3. Танцңювальна терапія (навчання танцям застосовується для позбавлення від комплексів, а також в якості профілактики неврозів).

4. Бібліотерапія (використовується для школярів, яким підбирають спеціальну літературу для відволікання від негативних думок, боротьби 3 неврозами та іншими проблемами емоційного плану).

5. Драматерапія (рольові ігри та сценки з нестандартними умовами, які допомагають дитині придбати комунікативні навички та адаптуватися в навколишньому світі).

6. Музикотерапія (співи, слухання музики і гра на музичних інструментах, що допомагає позбутися стресу і розвинути художні здібності).

7. Ігротерапія (за допомогою іграшок діти моделюють життєві ситуації, випускаючи назовні свої страхи i бажання, долають психологічні труднощі).

8. Кольоротерапія (завдяки підбору речей і предметів певного кольору дитина може вирішити безліч психологічних проблем).

9. Пісочна терапія (робота з піском заспокоює, допомагає перемогти комплекси та страхи, знімає емоційну напругу).

10. Лялькотерапія (створюючи ляльки, дитина вкладає в них власний біль, звільняючи себе від негативу; така терапія допомагає розкрити себе і позбутися від психологічних проблем).

11. Колаж робиться з газетних і журнальних вирізок, природних матеріалів, фотографій, кольорового паперу. При виготовленні колажу не виникає напруги, пов'язаної з відсутністю художніх здібностей, саме тому він дозволяє кожному одержати успішний результат.

12. Фототерапія. Робиться серія авторських фотографій, які потім аналізуються. Важливе використання сімейних фотографій, оскільки 48 
зображені події хоча й залишились у минулому, але підсвідомо вони продовжують впливати на людину. Фотографії допомагають пригадати минуле, усвідомити помилки, побачити образи.

13. Маскотерапія. Маска ліпиться на обличчі. Спочатку на шкіру наноситься крем, на який викладається перший шар паперу, а зверху приклеюється другий. Потім вона знімається й висушується, а далі розмальовується.

Отже, арт-терапія $\epsilon$ найбільш давньою та природною формою корекції емоційного стану, якою можна користуватись для зняття накопиченої психічної напруги, для того, щоб заспокоїтись чи просто зосередитись. Творчість як дитини, так і дорослого, реалізована у процесі арт-терапії, дає можливість висловити та відтворити внутрішні почуття, переживання, сумніви, конфлікти та сподівання, у символічній формі переживши ще раз важливі події, адже спонтанна образотворча діяльність здатна виражати неусвідомлюваний зміст психічного життя.

\title{
Література:
}

1. Киселева М. Арт-терапия в работе с детьми. Москва: Речь, 2014. $160 \mathrm{c}$.

2. Копытин А. Теория и практика арт-терапии. Санкт-Петербург: Питер, 2002. 368 c.

3. Никитин В. Арт-терапия. Москва: Когито-Центр, 2014. 336 с.

DOI https://doi.org/10.30525/978-9934-26-004-9-80

\section{КЛАРНЕТ У СИМФОНІЯХ ДМИТРА ШОСТАКОВИЧА В АСПЕКТІ ОСОБЛИВОСТЕЙ ОРКЕСТРОВОГО МИСЛЕННЯ}

\author{
Бойко П. А. \\ аспірант кафедри теорії та історії музичного виконавства \\ Науковий керівник: Качмарчик В. П. \\ доктор мистеитвознавства, професор \\ Національної музичної академії України імені П. І. Чайковського \\ м. Київ, Украӥна
}

Як відомо, Дмитро Шостакович - видатний композитор та симфоніст XX сторіччя, музикант трагічної долі. Складні обставини його мистецького життя були обумовлені тоталітарною епохою та моральною тиранією влади. Левон Акопян - дослідник творчості Д. Шостаковича 